\title{
The Effect of Brand Salience and Community on Brand Love, Loyalty and Brand Advocacy (Survey on Riamiranda Brand Customers in Indonesia)
}

\author{
Farida Akbarina* \\ State Polytechnic of Malang \\ Tundung Subali Patma \\ State Polytechnic of Malang \\ Sanita Dhakirah \\ State Polytechnic of Malang
}

\begin{abstract}
Consumers in their decision-making process have undergone changes, which were originally simple behaviors that have developed into complex and highly dynamic processes. The purpose of this study is to analyze the influence of brand salience and community on brand love, loyalty and brand advocacy" (a survey of Riamiranda brand customers in Indonesia). The approach used in this research is explanatory research (explanatory research) with a quantitative paradigm and survey methods. The research was conducted throughout Indonesia and was conducted with an online survey with the consideration to reach all respondents in Indonesia without borders (borderless). The population used is all Riamiranda customers in Indonesia. The number of the population cannot be known with certainty so that the sample in this study was determined using the Machin and Campbell (1989) formula so that the research sample was rounded off from the first iteration of 200 respondents. The sampling technique that can be used is purporsive sampling. The results show 1) Brand Salience has a positive and significant influence on Brand Love 2) Brand Salience has a positive and significant influence on Loyalty 3) Community has a positive and significant influence on brand love 4) Community has a positive and significant influence on loyalty 5) brand love has a positive and significant influence on loyalty. The brand salience variable has a dominant influence on brand love and loyalty so that if HRM wants to increase consumer loyalty, what must be considered is product knowledge,
\end{abstract}

Keywords: brand salience, brand love, community, loyalty

DOI: $10.7176 / \mathrm{JESD} / 12-20-03$

Publication date:October $31^{\text {st }} 2021$

\section{Introduction}

Consumers in their decision-making process have undergone changes, which were originally simple behaviors that have developed into complex and highly dynamic processes. This change is nothing but influenced by interactions with the environment both from within the company and from outside the company. The Theory of Reasoned Action (TRA) proposed by Fishbein and Ajzen (1975) is a theory of attitudes and/or behavior that creates a causal relationship between attitudes, subjective norms, behavioral intentions and behavior. This theory deals with awareness and the relationship between intention to do and a person's actual behavior. Consumers can feel immediately the results of doing positive behavior. Consumers will have a positive attitude to carry out future behavior. Furthermore, Fishbein and Ajzen (1975) suggested that behavioral intention which is a direct antecedent to behavior is a full belief to perform a certain behavior and will lead to certain results. Individual intention to perform behavior is a combination of attitude towards behavior and subjective norms which include behavioral beliefs, evaluation of behavioral outcomes, subjective norms, normative beliefs and motivation to behave.

Consumer behavior as mentioned by Sciffman and Kanuk (2008) reveals that the study of consumer behavior focuses on the way individuals make purchasing decisions related to consumption. Consumer behavior studies are needed to identify what consumers buy, why buy, when to buy, where to buy, how often to buy and how often to use. The study of consumer behavior allows marketers to understand consumer behavior in the purchase decision process embodied in the marketing concept.

Brand salienceis important because it strongly influences the purchase intentions of customers when they make purchasing decisions. When a customer makes a purchase for a brand that is in his mind, the experience of using the product that has been repeated has left a good impression and can lead to brand love. Consumers who have an understanding of the importance of brands for themselves, especially in the context of fashion, tend not to easily choose any brand for their clothing choices. Especially if the brand offers more value than other similar fashion brands. So that it can make customers become loyal.

Brand Salience(Shaw, 2010), is the tendency of the brand to be thought of by consumers or in other words 
the superiority of the brand and the image that stands out in the minds of consumers. Brand is used as a means of identifying the source of the product. As mentioned by Tjiptono and Chandra (2012), the company must have a good value obtained in order to make it easier for consumers to make the purchasing decision process. Consumer love for a product is one of the important elements in marketing the product, as a differentiator with similar products. Brand love serves to attract consumer interest, with good brand salience, can be easily remembered by consumers and can be influenced by consumers in making purchasing decisions. Oentoro (2012) stated that each brand has its own differences and advantages. Consumers will decide which brand to buy that best suits their wants and needs. The better the consumer feels about the product being sold, the more impact on consumer purchasing decisions.

Brand Love as the level of emotional attachment that satisfied customers have with a brand (Carroll et al andAhuvia, 2006). It can also include the emptiness the consumer feels when the brand is not with him. This is in line with Brand Advocacy where someone who already loves a particular brand will voluntarily become an advocate for the brand he loves because there is a feeling that no one can match the brand he loves.A person will not use a product if in his mind he does not feel confident in the product. According to Gefen (2003), love of a product is mediated by the importance of a brand and directly increases the intensity of buying behavior.

One of the key factors in business competition is strengthening customer loyalty to a brand, one of which is creating comfortable conditions for customers, loyalty is an invaluable asset and greatly determines the survival of the brand. This also applies to the creative industry, especially the fashion industry. Loyal consumers will generally continue to repurchase even though they are faced with competing products that offer superior product characteristics because they are already happy with the product. When loyalty has been formed strongly it will become an effective and efficient promotional media because loyal customers will provide recommendations to relatives and or friends,

Loyalty is understood as the consumer's desire to repurchase the product and continue the relationship with the provider (Cater and Cater, 2010). Customer loyalty is important primarily because of its positive effect on sales and the proportion of total customer purchases. Advocacy is the customer's desire to provide strong recommendations and praise for a product or brand to other consumers. Michael (2007) states that truly loyal customers can become advocates. Loyal customers believe that the brand is the best and they want to stay with the brand to make additional purchases, and become advocates.

Various studies have also proven the importance of Loyalty which is built on the foundation of long-term relationships, these relationships can occur between people and companies or between companies. Griffin (2007) emphasizes the process of creating customer loyalty as an interpersonal relationship that occurs between customers and company services. Griffin (1995) further explained that there are two main factors in building loyalty, namely attention to the "value" of the product or service produced and building relationships with customers.

Many consumer behavior studies support the idea that loyalty and advocacy are distinct but related constructs. Michael (2007) distinguishes by saying that truly loyal customers can become advocates. Samson (2006) says that loyalty is related to customer retention while advocacy is related to customer acquisition, further mentioning that recommendation in loyalty is an attitude or desire to recommend, while recommendation in advocacy is the act of providing recommendations to other parties. Brand loyalty or customer loyalty is an important concept for many companies that can bring many benefits to companies, such as repeat purchases and recommendations of the brand to others, which in turn can reduce marketing costs. Along with the development of industry, entertainment, information and technology, a person's style of dress is used to show his existence in society. By following a certain fashion, one can show their true identity. Based on the description above, the authors are interested in conducting research on Brand Salience, Community, Brand Love, and Loyalty.

Consumer desires that are constantly changing should make marketers pay more attention and then accommodate all these desires. Product development is a concrete manifestation of a marketer's strategy to bridge the changing desires of consumers. One of the sectors that is experiencing dynamic changes is the fashion business. This business requires a quick response in the form of designer or company creativity to meet changing demands.

Fashion is an important part for humans who are very dependent on its existence if the product is scarce (Woodward, 2007). This ever-changing fashion will be useful for the study of consumer behavior (Eicher and Higgins, 1992). The term fashion refers to all items attached to the human body. Fashion, especially Muslim fashion in Indonesia, currently allows for potential because one's need to be responsive to fashion will determine one's self-esteem so that from a fashion marketing perspective, producers need to be productive to develop their business. On the other hand, Muslims demand Muslim products which are the latest prospects of the fashion market around the world. The relationship is that if the market does not penetrate the product into the Muslim market, the company's sustainability will be threatened (Morphitou and Gibbs, 2004).

Companies engaged in the fashion sector are very dependent on customers who make repeat purchases to achieve loyalty and are often willing to advocate for a brand if the product is able to meet fashion needs that are stylish, durable, easy to care for, comfortable, valuable and all other criteria deemed relevant. . Along with the increase in people's welfare, the consumption of goods other than basic needs is also increasing. One of them is 
the need to consume fashion products that arise from people's needs to increase comfort and satisfaction. Referring to Lewitt's (1960) research on the marketing concept for the "managerial marketing" implications, among others, define and describe the potential target market so that this can be handled effectively with appropriate products and relevant and effective advertising (Houston, 1986). The criteria used to distinguish the target market based on socio-demographic examples, implicitly assume that close friends who have the same age, education and income tend to share their consumption preferences and behavior.

The trend of using Muslim clothing in Indonesia continues to experience rapid development. This is a natural thing considering that Indonesia is a country with the largest Muslim population in the world as shown in Table 1 Table 1 Population of Islam in the World

\begin{tabular}{|c|c|c|r|}
\hline Rank & Country code & Country & Population \\
\hline 1 & ID & Indonesia & $270,625,568$ \\
\hline 2 & PK & Pakistan & $216,565,318$ \\
\hline 3 & NG & Nigeria & $160,963,5949$ \\
\hline 4 & BD & Bangladesh & $100,388,073$ \\
\hline 5 & EG & Egypt & $83,429,615$ \\
\hline 6 & TR & Turkey & $82,913,906$ \\
\hline 7 & IR & Iran & 43.053 .054 \\
\hline 8 & DZ & Algeria & $42,813,238$ \\
\hline 9 & SD & Sudan & $39,309,783$ \\
\hline 10 & IQ & Iraq & \\
\hline
\end{tabular}

Source : worldpopulationreview.com (2019)

Based on Table 1, it is known that over time, the majority of Indonesian people embraced Islam, starting to make Muslim clothing part of the main fashion item. If we look at the history of closed clothing, such as Muslim clothing, it is not clothing that is quite familiar to Indonesian society before. However, along with the understanding of Islamic teachings that are believed by the majority of Indonesian people, Muslim clothing continues to be widely accepted. The use of Muslim clothing began to be widely worn after the development of the hijab was accepted. This can be seen from the many photos of Indonesian women in the 1940s who combined long or short sleeves with a simple hijab, which only served as a head covering. The progress of the times and the ease of entry of culture from abroad, make the development of Muslim clothing continues to evolve. These developments also encourage the variety of Muslim fashion styles from time to time throughout the world, including Indonesia. The Ministry of Industry noted that Muslim fashion began to bloom in Indonesia since the 1990s and grew rapidly in the next 10 years. Since then, more and more people have started to look at Muslim clothing.

The variety of Indonesian arts and culture has inspired many in designing and it is also recognized that Indonesian Muslim clothing has added value. The variety of batik and weaving motifs makes designs by local designers quite distinctive, so it is not difficult to find market share. The long and polite silhouette of clothing makes Muslim clothing also has a market share, not only those who are Muslim. Moreover, now the clothing designs continue to follow the development of world fashion, by being adapted through hijab fashion items, the reach of the Indonesian Muslim fashion market is getting wider.

One of the designers who is trusted to display their best work at the world fashion week held in London or familiarly called London Fashion Week is Riamiranda. Given the increasing demand and interest in Muslim fashion users, there are figures who stand out and even become a separate trend for Muslim fashion connoisseurs or consumers. Riamiranda, a Muslim fashion designer who is able to create differences in Muslim dress styles for women in Indonesia and even the world with the trend of hijab styles and attractive Muslim clothes combined with beautiful and unique motifs.

As a designer, it is an achievement to be involved in a fashion stage that is held on a global scale. Riamiranda in his journey for a decade has displayed his work in various prestigious fashion shows at the world level. This has also attracted the attention of researchers to study the Riamiranda brand further. Because at the beginning, Riamiranda participating in fashion shows was a foreign thing for world fashion connoisseurs when there were designers who displayed clothes with hijab. Meanwhile, other designers who appeared on the same stage were non-hijab clothing designers.

Efforts to fulfill consumer confidence in using the product are by officially testing the product. This is an important concern for Muslim fashion companies to make consumers believe in the products offered and make their products superior in the market. The impact of trust that arises in consumers can also make a brand big and famous and even indirectly consumers can also act as "sellers". This is also mentioned by Buil and Chernatony (2014) in their research regarding the influence of Brand Love, Brand Advocacy and Loyalty. Brand Love as a consumer experience is very good because it shows the identity of the consumer, resulting in the formation of a strong emotional bond with the brand. 


\section{Theory}

\subsection{Brand Salience}

According to Remaud and Lockshin (2009), the significance of the brand refers to where a particular brand comes to mind when talking about products related to product brands. Iba and Chattopadhyay (1986) defined brand salience as the level of salientness in memory associated with an emotional response that leads to an expected increase in brand salience. The significance of the brand is important because it greatly influences the buying interest of customers when they make a choice about which product or brand product to buy (Hong, et al. 2008). Miller and Berry (1998), stated that better positioned products take advantage and trigger customer purchase intentions. Brands that are a person's top choice and top priority also stand out. Romaniuk and Sharp (2003), argues that there are other ways through which this brand salience can be expressed such as the attributes of a brand, which means that the customer will remember and the brand will remain in his subconscious through the attributes that distinguish consumers are related to the brand name and which are related to the brand name. will differentiate the brand from competitors. Salience is abstracted as the possibility of what the customer thinks about the brand at a certain point when something comes to his mind

\subsection{Community}

According to Syahyuti (2003), community is a group of people who live together in the same location, so that they have developed into a group of lives (group lives) bound by common interests (common interests). In sociology, the literal meaning is the local community (Soekanto, 1999), namely a group of people who live together in such a way that they feel that the group can fulfill the main life interests. This means that there is a strong social relationship between them, in a certain geography. Factors that form the basis of intensive interaction among its members, compared to people outside their boundaries. So the measure is the degree of social relationship. Community effect (community effect) or often called the Bandwagon effect (herd instinct) people often follow the crowd without examining the benefits of certain things http://en.wikipedia.org/wiki/bandwagon_effect). Meanwhile, according to Rohlf (2001), Bandwagon effect is a benefit that is enjoyed by someone as a result of other people doing the same thing we do. In particular, a consumer enjoys the benefits of a bandwagon when other people consume the same product or service that we do.

\subsection{Brand Love}

Brand love The brand as a consumer experience is best represented as a higher-order construct including several cognitions, emotions, and behaviors that consumers organize into mental prototypes. These include, but extend beyond, brand attachment (Thomson, et al., 1995) and self-brand connection (Escalas and Bettman 2003). Research conducted by Batra et al., (2012) developed a valid and rigorous equation structure model of a prototype brand love that, due to its foundation in two qualitative studies, used significantly wider range of emotional and self-related constructs than previous work (eg, a natural sense of comfort). and compatibility, feelings of emotional connectedness and bonding, deep integration with consumer core values, high level of desire and interaction, commitment to long-term use

\subsection{Loyalty}

Understanding Consumer Loyalty Griffin and Jill (2005) states that: "Loyalty is defined as non random purchase expressed over time by some decision making unit". From this understanding, it can be seen that loyalty refers to a behavior that is aimed at routine purchases based on the decision-making unit. According to Shet in Tjiptono (2000:110) states that: "Loyalty is a customer's commitment to a brand, store, or supplier which is reflected in a very positive attitude and a form of repeat purchase behavior made by the customer consistently. " From this understanding, it can be seen that loyalty is something very important that has a direct effect on profitability. Loyalty reflects how likely someone will switch to another company. With the level of loyalty from customers, it will reduce the vulnerability to competition. Consumer loyalty is a consumer's commitment to a brand, store or supplier based on positive traits and is reflected in consistent repeat purchases

\section{Research Method}

The research paradigm used in this study is a quantitative research paradigm with survey methods. The approach used is explanatory research (explanatory research). This research took place throughout Indonesia and was carried out with an online survey with the consideration of reaching all respondents in Indonesia without borders (borderless). The population used is all Riamiranda customers in Indonesia with the criteria of 1) purchasing Riamiranda products at least 1 time in the last 6 months 2) female, 3) at least 18 years old, 4) Respondents are buyers who buy on its own decision, 5) Respondents make purchases for personal use and not for resale purposes. The number of the population cannot be known with certainty so that the sample in this study was determined using the Machin and Campbell (1989) formula. Based on the calculation of the formula of Machin and Campbell (1989), so the research sample is a rounding off from the first iteration, which is a number of 200 respondents. The 
sampling technique that can be used is non-random sampling. While the technique used to determine the sample is using purposive sampling.

Data collection in this study was carried out by distributing online questionnaires via line, whatsapp, telegram and Instagram. Respondents' answers were measured using a Likert scale. Furthermore, the indicator on the Brand Salience variable (X1) uses the theory of Jraisat, et al., (2016) and Vieceli and Shaw (2010), the indicator on the Community variable (X2) uses the theory of Muniz and O'Guin (2001), the indicator on Brand Love(Y1) variable uses the theory of Wallace et al. (2014) and on the Loyalty variable (Y2) using the Shimul and Phau (2018) indicator. The data that has been collected was analyzed using the Structural Equation Modeling (SEM) method with the Partial Least Square (PLS) 3.0 path.

\section{Result}

The results of this study are divided into three parts, namely a description of the respondent's profile, the results of the outer model, the results of the inner modal and the results of hypothesis testing.

\subsection{Respondent profile}

The results showed that 168 respondents who had filled out the questionnaire were female (84\%) and as many as 98 respondents (49\%) have an income of 3,000,001-6,000,000. Furthermore, as many as 127 respondents (63.5\%) shopped at HRM East Java for their own needs, 122 respondents (61\%) shopped at HRM East Java shopped for HRM products 2 times and as many as 89 respondents (44.5\%) know the HRM brand from a friend.

\subsection{Outer Model Results}

\subsubsection{Convergent Validity}

Convergent validity aims to evaluate the results of the validity test values of each latent variable with its indicators. Ghozali and Latan (2012) argue that for research in the early stages of development, the measurement scale of the loading factor value of 0.5 to 0.6 is considered adequate so that the loading factor value used as a reference for evaluating the measurement model in this study is $>0.5$. The results of the study indicate that the overall item loading factor value is $>0.5$ so it can be said to be valid. The results of the loading factor values in detail can be seen in Table 1.

Table 2. Value of Loading Factor

\begin{tabular}{|l|c|c|c|c|}
\hline & Brand Love & Brand Salience & Community & Loyalty \\
\hline X1.1 & & 0.713 & & \\
\hline X1.10 & & 0.730 & & \\
\hline X1.2 & & 0.638 & & \\
\hline X1.3 & & 0.628 & & \\
\hline X1.4 & & 0.695 & & \\
\hline X1.5 & & 0.759 & & \\
\hline X1.6 & & 0.682 & & \\
\hline X1.7 & & 0.633 & & \\
\hline X1.8 & & 0.631 & & \\
\hline X1.9 & & 0.762 & & \\
\hline X2.1 & & & 0.634 & \\
\hline X2.2 & & & 0.670 & \\
\hline X2.3 & & & 0.750 & \\
\hline X2.4 & & & & \\
\hline X2.5 & & & & \\
\hline X2.6 & & & & \\
\hline Y1.1 & 0.652 & & & \\
\hline Y1.2 & 0.726 & & & \\
\hline Y1.3 & 0.720 & & & \\
\hline Y1.4 & 0.727 & & & \\
\hline Y1.5 & 0.704 & & & \\
\hline Y1.6 & 0.691 & & & \\
\hline
\end{tabular}




\begin{tabular}{|l|c|c|c|c|}
\hline & Brand Love & Brand Salience & Community & Loyalty \\
\hline Y1.7 & 0.775 & & & \\
\hline Y1.8 & 0.672 & & & \\
\hline Y2.1 & & & & 0.757 \\
\hline Y2.2 & & & & 0.586 \\
\hline Y2.3 & & & & 0.729 \\
\hline Y2.4 & & & & 0.790 \\
\hline
\end{tabular}

\subsubsection{Discriminant Validity}

Discriminant Validity aims to prove the construct of the latent variable to predict the size of the variable construct value which is larger than the size of the correlation value of the other variables. Discriminant Validity is seen from the cross loading value of the research results. The results of the cross loading value of discriminant validity testing can be seen in the following table:

Table 3. Discriminant Validity

\begin{tabular}{|c|c|c|c|c|}
\hline & Brand Love & Brand Salience & Community & Loyalty \\
\hline X1.1 & 0.501 & 0.713 & 0.528 & 0.514 \\
\hline $\mathrm{X} 1.10$ & 0.623 & 0.730 & 0.565 & 0.564 \\
\hline $\mathrm{X} 1.2$ & 0.431 & 0.638 & 0.400 & 0.423 \\
\hline $\mathrm{X} 1.3$ & 0.448 & 0.628 & 0.417 & 0.424 \\
\hline X1.4 & 0.553 & 0.695 & 0.551 & 0.491 \\
\hline X1.5 & 0.623 & 0.759 & 0.572 & 0.576 \\
\hline X1.6 & 0.571 & 0.682 & 0.553 & 0.554 \\
\hline X1.7 & 0.464 & 0.633 & 0.465 & 0.413 \\
\hline $\mathrm{X} 1.8$ & 0.428 & 0.631 & 0.482 & 0.454 \\
\hline X1.9 & 0.598 & 0.762 & 0.546 & 0.574 \\
\hline X2.1 & 0.478 & 0.464 & 0.634 & 0.521 \\
\hline $\mathrm{X} 2.2$ & 0.444 & 0.421 & 0.670 & 0.480 \\
\hline X2.3 & 0.533 & 0.473 & 0.698 & 0.520 \\
\hline X2.4 & 0.571 & 0.570 & 0.750 & 0.623 \\
\hline $\mathrm{X} 2.5$ & 0.513 & 0.536 & 0.646 & 0.442 \\
\hline X2.6 & 0.527 & 0.594 & 0.726 & 0.528 \\
\hline Y1.1 & 0.652 & 0.501 & 0.548 & 0.477 \\
\hline Y1.2 & 0.726 & 0.557 & 0.507 & 0.589 \\
\hline Y1.3 & 0.720 & 0.592 & 0.530 & 0.609 \\
\hline Y1.4 & 0.727 & 0.560 & 0.571 & 0.557 \\
\hline Y1.5 & 0.704 & 0.477 & 0.476 & 0.527 \\
\hline Y1.6 & 0.691 & 0.532 & 0.523 & 0.538 \\
\hline Y1.7 & 0.775 & 0.642 & 0.579 & 0.581 \\
\hline Y1.8 & 0.672 & 0.487 & 0.486 & 0.583 \\
\hline Y2.1 & 0.658 & 0.555 & 0.590 & 0.757 \\
\hline Y2.2 & 0.421 & 0.479 & 0.463 & 0.586 \\
\hline Y2.3 & 0.547 & 0.490 & 0.511 & 0.729 \\
\hline Y2.4 & 0.614 & 0.575 & 0.605 & 0.790 \\
\hline
\end{tabular}

Based on table 3, it shows that the main cross loading value of the constructs of brand salience, community, brand love and loyalty is greater than the correlation value built from these variables to other constructs so that it can be declared a valid discriminant.

\subsubsection{Composite Reliability}

Composite Reliability is an evaluation of the measurement results by comparing the AVE value with the correlation value between constructs. After that, an evaluation was carried out by looking at the composite 
reliability and Cronbach alpha values to assess the reliability of the variable construct. The construct is declared reliable if the composite reliability value is above 0.70 . Composite Reliability results in detail are presented in Table 4.12.

Table 3 Results of Composite Reability

\begin{tabular}{|c|c|c|c|c|c|}
\hline & $\begin{array}{l}\text { Cronbach's } \\
\text { Alpha }\end{array}$ & $\begin{array}{l}\text { rho_ } \\
\text { A }\end{array}$ & $\begin{array}{l}\text { Composite } \\
\text { Reliability }\end{array}$ & $\begin{array}{l}\text { Average } \\
\text { (AVE) }\end{array}$ & Extracted \\
\hline Brand Love & 0.858 & 0.860 & 0.890 & & 0.503 \\
\hline $\begin{array}{l}\text { Brand } \\
\text { Salience }\end{array}$ & 0.876 & 0.883 & 0.900 & & 0.575 \\
\hline Community & 0.777 & 0.782 & 0.844 & & 0.574 \\
\hline Loyalty & 0.786 & 0.701 & 0.809 & & 0.518 \\
\hline
\end{tabular}

Based on the table above, it can be concluded that the evaluation of the measurement model in this study has good discriminant validity, it can be seen that the overall AVE value is not less than 0.5 . The Composite Reliability value in each variable construct also has good reliability, it can be seen that the Composite Reliability value in each variable can be said to have high reliability because it has a value $>0.70$.

\subsection{Inner Model Results}

\subsubsection{R-Square (R2)}

According to Ghozali and Latan (2012) when using the SEM-PLS inferential statistical test termed the structural model (Inner Model) seen through the value of R-square (R2) with a value of 0.67 is a strong influence, 0.33 gives an indication of a moderate effect. and 0.19 indicates a weak effect. The test results can be seen in detail in Table 4.13 .

Table 4 Results of R Square . Value

\begin{tabular}{|l|r|r|}
\hline Variable & R Square & Information \\
\hline Brand Love & 0.659 & Currently \\
\hline Loyalty & 0.697 & Strong \\
\hline
\end{tabular}

Based on table 4.13 above, it can be seen that the Brand Love variable has an R-square value of 0.659 which gives an indication of moderate influence in other words the Brand Love variable can be influenced by Brand Salience and Community variables by $65.9 \%$ and the rest can be influenced by other variables. Loyalty variable has an R-square value of 0.697 which indicates a strong influence in other words Loyalty variable can be influenced by Brand Salience, Community and Brand Love by $69.7 \%$ and the rest can be influenced by other variables

\subsubsection{Predictive Relevance $\left(Q_{2}\right)$}

In the results of the SEM-PLS model, the overall goodness of fit assessment is known from the value of Q2 (predictive relevance). The goodness of fit model testing is carried out using the coefficient of total determination, where the test results can explain how much the path model formed is able to represent the observed data. Based on Table 5.17 regarding the R-square value, the predictive relevance can be calculated as follows:

$$
\begin{aligned}
& \mathrm{Q} 2=1-(1-\mathrm{R} 12) \times(1-\mathrm{R} 22) \\
& \mathrm{Q} 2=1-(1-0.659) \times(1-0.697) \\
& \mathrm{Q} 2=1-(0.341 \times 0.303) \\
& \mathrm{Q} 2 \text { value }=1-0.103 \\
& \mathrm{Q} 2 \text { value }=0.897
\end{aligned}
$$

Based on the results of the calculation of the Q2 value above, it can be seen that the Q2 value is 0.897 which means that the diversity of data from the structural equation model designed can be explained by $89.7 \%$ and the remaining $10.3 \%$ is explained by other factors outside the research model used so that the structural model In this study, it can be stated that it has a good goodness of fit because the magnitude of Q2 has a value with a range of 0 $<\mathrm{Q} 2<1$, where the closer to 1 , the better the model.

\subsubsection{Hypothesis testing}

The results of testing the research hypothesis using the bootstrapping method from the structural model equation can be seen in Table 4.14 which presents the relationship between latent variables and the relationship between latent variables and their manifest variables. 
Table 5 Hypothesis Test Results

\begin{tabular}{|c|c|c|c|c|c|c|}
\hline 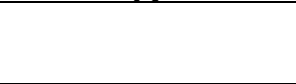 & & $\begin{array}{l}\text { Original } \\
\text { Sample (O) }\end{array}$ & $\begin{array}{l}\text { Sample } \\
\text { Mean (M) }\end{array}$ & $\begin{array}{l}\text { Standard Deviation } \\
\text { (STDEV) }\end{array}$ & $\begin{array}{l}\text { Tr Statistics } \\
(|\mathrm{O} / \mathrm{STDEV}|)\end{array}$ & P Values \\
\hline $\begin{array}{l}\text { Brand Love - } \\
\text { Loyalty }\end{array}$ & & 0.418 & 0.431 & 0.065 & 6,403 & 0.000 \\
\hline $\begin{array}{l}\text { Brand Salience - } \\
\text { Brand Love }\end{array}$ & $->$ & 0.484 & 0.485 & 0.075 & 6,433 & 0.000 \\
\hline $\begin{array}{l}\text { Brand Salience - } \\
\text { Loyalty }\end{array}$ & $->$ & 0.172 & 0.166 & 0.071 & 2,425 & 0.016 \\
\hline $\begin{array}{l}\text { Community } \\
\text { Brand Love }\end{array}$ & $->$ & 0.385 & 0.388 & 0.074 & 5,228 & 0.000 \\
\hline $\begin{array}{l}\text { Community } \\
\text { Loyalty }\end{array}$ & $->$ & 0.319 & 0.314 & 0.077 & 4.156 & 0.000 \\
\hline
\end{tabular}

Based on Table 5 above, the results of hypothesis testing can be described as follows:

1. $\mathrm{H} 1=$ Brand Salience has a significant effect on Brand Love

The results of the $\mathrm{H} 1$ test show that the path coefficient of the experience quality variable on the customer perceived value is 0.484 with a t-count value of 6.433 and a p-value of 0.000 . The t-count value shows a value greater than the t-table, which is 1.960 and the $p$-value shows a value less than 0.05 . These results indicate that Brand Salience has a positive and significant influence on Brand Love, so it can be said that the first hypothesis proposed in this study is accepted.

2. $\mathrm{H} 2=$ Brand Salience has a significant effect on loyalty

The results of the $\mathrm{H} 2$ test show that the path coefficient of the Brand Salience variable on loyalty is 0.172 with a t-count value of 2.425 and a p-value of 0.016 . The t-count value shows a value greater than the t-table, which is 1.960 and the p-value shows a value less than 0.05 . These results indicate that Brand Salience has a positive and significant influence on Loyalty, so it can be said that the second hypothesis proposed in this study is accepted.

3. $\mathrm{H} 3=$ Community has a significant effect on Brand Love

The results of the $\mathrm{H} 3$ test show that the path coefficient value of the community variable towards brand love is 0.385 with a t-count value of 5.228 and a p-value of 0.000 . The t-count value shows a value greater than the $t$-table, which is 1.960 and the $p$-value shows a value less than 0.05 . These results indicate that Community has a positive and significant influence on brand love, so it can be said that the third hypothesis proposed in this study is accepted.

4. $\mathrm{H} 4=$ Community has a significant effect on loyalty

The results of the $\mathrm{H} 4$ test show that the path coefficient value of the community variable towards loyalty is 0.319 with a t-count value of 4.156 and a $p$-value of 0.000 . The $t$-count value shows a value greater than the t-table, which is 1.960 and the p-value shows a value less than 0.05 . These results indicate that community has a positive and significant influence on loyalty so that it can be said that the fourth hypothesis proposed in this study is accepted.

5. $\mathrm{H} 5=$ brand love has a significant effect on loyalty

The results of the $\mathrm{H} 5$ test show that the path coefficient value of the brand love variable on loyalty is 0.418 with a t-count value of 6.403 and a p-value of 0.001 . The t-count value shows a value greater than the t-table, which is 1.960 and the p-value shows a value less than 0.05 . These results indicate that brand love has a positive and significant influence on loyalty so that it can be said that the fifth hypothesis proposed in this study is accepted

\section{Discussion}

\section{H1: Brand Salience has a significant effect on Brand Love}

The suitability between the consumer's self-image and the user's image of a brand as a driver of consumer decision making in buying a product or service of a brand, Ericksen (2005). In addition, consumers often perceive a brand as like themselves, Bairrada, Coelho, \& Lizanets, (2019) and consumers tend to judge and develop their love for a brand if the brand is in accordance with the concepts and values that reflect the consumer's personality, Bıçakcığlu et al., (2016); Holzer, Batt, \& Bruhn, (2016). Based on the analysis results, Brand Salience has an effect on Brand Love with the coefficient value showing a positive result of 6.433 and the p-value ***, which means the value of $\mathrm{p}<0.05$. These results indicate that $\mathrm{H} 1$ has a positive effect on and is supported by the data.

\section{H2: Brand Salience has a significant effect on Loyalty}

From the analysis of this research, it can be found that the influence of Brand Salience on Customer Loyalty is very small. Judging from the results of T-statistics with a value of 2.425 , the effect is not significant even though there is a positive relationship. According to Aaker (1991) suggests that brand awareness can affect perceptions and loyalty. But the most important thing is that someone who is loyal is definitely aware. However, someone who 
is aware of the brand of a product, is not necessarily loyal to the product. In the case of this study, a customer will be loyal if he already knows about the Riamiranda brand.

\section{H3: Community has a significant effect on Brand Love}

Nazari, Leylan, and Panahandeh (2014) found that brand community has a positive effect on word of mouth communication in the context of textiles and cars. In addition, Wallace, Buli, and Chernatony (2014) show that brand community is positively related to word of mouth communication in the context of products that use Facebook as a distribution channel. Based on the results of hypothesis testing, it can be concluded that the community variable has a positive and significant influence on the brand love variable. Based on these results, it can be seen that if the community variable is increased, the brand love will also increase. This is in accordance with the opinion Hegner et al. (2017) that Brand love is considered as one of the highest goals of brand managers. Undeniably, brand love can have positive ramifications for brand reputation and financial assets such as positive word-of-mouth or willingness to pay a premium price (Batra et al., 2012; Albert and Merunka, 2013).

\section{H4 : Community significant effect on Loyalty}

Based on the results of hypothesis testing, it can be concluded that the community variable has a positive and significant influence on the loyalty variable. Based on these results, it can be seen that if the community variable is increased, loyalty will also increase. This is in accordance with the research objectives of Jraisat et al. (2015) which to find out perceived brand salience, perceived brand quality and perceived image dimensions (physical environment and people's characteristics) are strategic constructs and interact in complex ways to create loyalty. Based on this, it can be concluded that community is one of the variables forming loyalty.

\section{H5 : Brand Lovesignificant effect on Loyalty}

Brand love affects loyalty attitudes that have an impact on consumer relationships with brands in the long term, Bairrada et al., (2019). The theory of reasoned action assumes that consumer behavior is determined by intention, which is attitude towards behavior which means feelings about likes or dislikes in behavior, Hansen et al., (2004). Intentions are based on a favorable attitude in behavior where the passionate brand love felt by consumers for a brand is the main driver of brand loyalty, Tsai (2011). Brand Love has an effect on Brand Loyalty with the coefficient value showing a positive result of 6.413 and the $p$-value $* * *$ which means the value of $p<0.05$. These results indicate that $\mathrm{H} 5$ has a positive effect on and is supported by the data.

The conclusion of this study is that Brand Salience has a positive and significant effect on Brand Love, Community has a positive and significant effect on Brand Love, Brand Salience has a positive and insignificant effect on Loyalty, Community has a positive and significant effect on Loyalty and Brand Love has a positive and significant effect on Loyalty.

\section{Conclusion}

Based on the results of the research that has been done, it can be concluded that there is a positive and significant influence between the brand salience variables with brand love and loyalty where in this case consumers who know HRM products will like these products and do not want to switch to other products. Community has a positive and significant influence on brand love and loyalty where in this case people who know HRM products will follow every product development and buy products they like and will continue to buy HRM products if there is something new. In addition, the results of this study also prove that brand love has a positive and significant effect on loyalty, thus it can be concluded that consumers who already like HRM products will become loyal consumers of HRM products. Brand salience has the most dominant influence on brand love and brand love also proves a high influence on brand loyalty so that it can be concluded that consumers who have understood HRM products will feel proud and like HRM products then they will be loyal to HRM products. Loyalty can be seen from proof of repeated purchases and recommending HRM products to others. Based on the results of the study, it can be seen that the brand salience variable has a dominant influence on brand love and loyalty so that if HRM wants to increase consumer loyalty, what must be considered is product knowledge. wide community

\section{References}

Bairrada, CM, Coelho, A., \& Lizanets, V. (2019). The impact of brand personality on consumer behavior: the role of brand love. Journal of Fashion Marketing and Management, 23(1), 30-47. https://doi.org/10.1108/JFMM07-2018-0091

Ericksen, MK (2005). Using Self-congruity and Ideal Congruity to Predict Purchase Intention. Journal of Euromarketing, 6(1), 41-56. https://doi.org/10.1300/j037v06n01_04

Hansen, T., Jensen, JM, \& Solgaard, HS (2004). Predicting online grocery buying intention: A comparison of the theory of reasoned action and the theory of planned behavior. International Journal of Information Management, 24(6), 539-550. https://doi.org/10.1016/j.ijinfomgt.2004.08.004

Muniz, AM Jr. And TC O'Guinn. 1995. Brand Community D, Journal of Consumer Research, 27(4): 412-32

Nazari, M., Leylan, LT, \& Panahandeh, A. (2014). The Role of Brand Love and Excitement in the Word of Mouth. Switzerland Research Park Journal, 103(1),304-313 
Unal, S., Aydin, H. (2013). An Investigation on the Evaluation of the Factors Affecting Brand Love. Procedia Social and Behavioral Sciences, 92, 6-85.

Wallace, E., Buil, I., \& Chernatony, L. (2014). Consumer engagement with self-expressive brands: brand love and WOM outcomes. Journal of Product and Brand Management, 23 (1), 33 - 42 